DOI https://doi.org/10.18551/rjoas.2018-05.18

\title{
THE EFFECT OF FUND ALLOCATION OF SPECIAL AUTONOMY OF ECONOMICAL GROWTH IN WEST PAPUA PROVINCE
}

\author{
Aninam Johny*, Maryunani, Susilo \\ Master's Program in Economics, University of Brawijaya, Indonesia \\ E-mail: johnyaninam@yahoo.co.id
}

\begin{abstract}
Indonesian central government's policy on special autonomy for West Papua regional government stands on Act \# 21 of 2001. It is accompanied with the policy of regional addition of West Papua province in accordance to Act \#35 of 2008. Under its special autonomy, West Papua has its own authority and fund called Special Autonomy Fund. This fund is oriented to support five areas considered important to indigenous West Papua people. They include education, health, infrastructure, people's economy and affirmation/other areas. The study applies secondary data from library study, generalized structured component analysis method for data analysis concerning the effect of fund allocation on economic growth in West Papua province. The result confirms that fund allocation does not have an effect on economic growth in West Papua.
\end{abstract}

\section{KEY WORDS}

Special autonomy, fund, economic growth, regional development, local regulations.

Indonesia is an archipelago country with its diversity in races, religions, languages, and customs. This on one hand is that makes Indonesia different from most other countries. On other hand however, it poses challenges with disintegration effects.

One strategy central government has followed to spur the development in West Papua as a measure to ensure equal welfare especially when compared to other regions is to provide special autonomy for the former under decentralization perspective. This measure is accompanied with the provision of Special Autonomy Fund since 2009 the amount of which is determined by central government's budget and regional development needs. The distribution follows the arrangement that $70 \%$ and $30 \%$ are respectively for Papua as the main province and West Papua province. The arrangement is based on consideration of several comparative indicators such as population number, region size, and villages. The total fund it has received yearly since 2009 to 2015 amounts to IDR $11,307,488,761,950$.

Based on special autonomy policy accompanied with subsequent fund, the study intends to explore the direct and indirect effects of the fund on economic growth in West Papua Province. Moreover, it intends to find out factors related to special autonomy fund that hinder its governance.

\section{LITERATURE REVIEW}

Decentralization is authority provision by central government to Autonomous regional government to govern and manage public services. Decentralization put government much closer to its public. According to Henry Maddick (1963) decentralization isa legal authority provision to a lower region to run some fields/functions. Rondinelli, Nellis, and Chema (1983) define decentralization as reinforcement, financially and legally, ofsub-national governments to run certain affairs on their own. Rondinelli (1983) defines decentralization as central government's provision of planning, decision-making, or authority to regional governments, semi-autonomous organizations, or non-governmental organizations.

Keynes has argued in The General Theory that total income in one economy in shortterms has necessarily been determined by households, companies and governments' spending. The more participants active in economy, the products and services consumed, and the more people employed (Mankiw, 2007). 
One purpose in development is economic growth (Kuncoro, 2004). Autonomy enables regional government to make its own decision-making in fund governance. This makes regional economic growth possible.

Logical consequence of this autonomy is fund for regional governments to run their affairs on their own terms. For the case of Papua, the provinces of Papua and West Papua has earned fund since 2002 and 2008, amounting to respectively.

According to Boediono (1985), economic growth is a long-term per capita output increase process. It comprises three dimensions, those are process aspect, per capita output aspect, and long-terms aspect. Accordingly, economic growth is a long term process related to per capita output increase. It implies that economic growth covers theories of gross domestic product (PDB) and of population growth. Todaro and Smith (2004) define economic growth as a production output increasingly supported by more production factors. Sukirno (2005) defines economic growth as activity development in economy resulting on the increased number of products and services made available in a society leading to heightened welfare. Arsyad (2004) pinpoints economic growth as an increased Gross Domestic Product (GDP) or Gross National Product (GNP) regardless of whether that this increase is above or below population growth, or whether it is related to changes in structural economy.

Mualim 'research (2010:101) concerning the effect fiscal decentralization on economic growth in West Papua argues that random effect can be applied to estimate the effect of fiscal decentralization in West Papua on its economic growth. Subroto's work (2011:230) concerning the effects of balanced fund and special autonomy fund on economic growth in regencies/municipalities of Papua province shows insignificant effect of the general allocation fund on economic growth, and significant effect of special autonomy fund on economic growth.

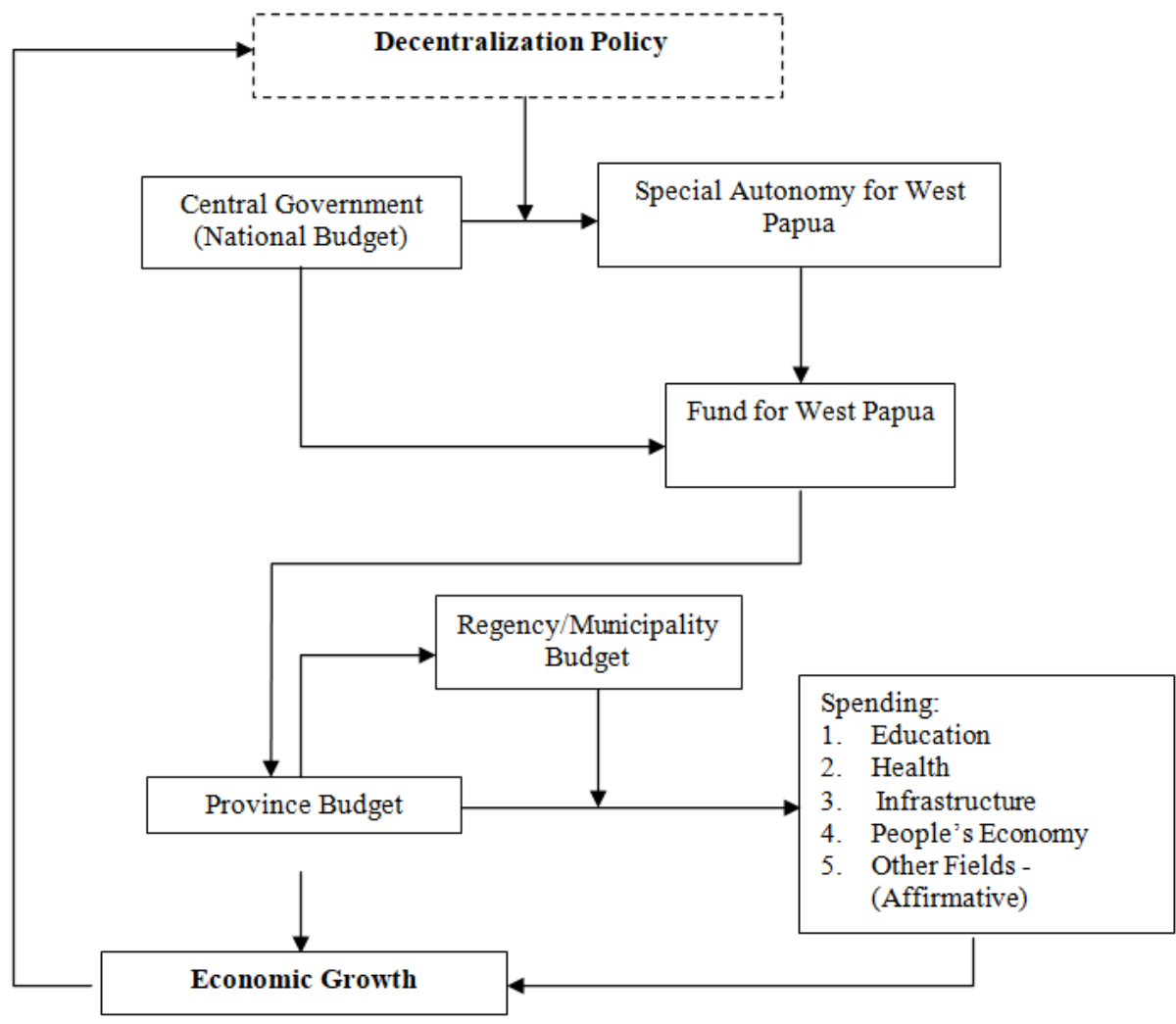

Figure 1 - Research Conceptual Framework

The study of Centre of Regional Study and Information concerning the effect of special autonomy fund on public welfare finds that special autonomy fund increases school 
participation rate, literacy rate, health, infrastructure, and decreased poverty rate in Papua and West Papua. This effect is however overshadowed by trend of increasing amount of special autonomy fund received by Papua and West Papua since 2001 to 2015.

The framework is triggered by the question of to what extent Central government's good government initiative reflected in policy of Regional autonomy for Papua and West Papua in the form of special autonomy based on Decentralization theory has any effect on economic growth in the two provinces. It is illustrated in the Figure 1.

Thus, the following hypotheses are formulated:

- It is assumed that special autonomy fund allocation has an effect on economic growth of West Papua.

- It is assumed that special autonomy fund through fund for education sector has an effect on economic growth of West Papua.

- It is assumed that special autonomy fund through fund for health sector has an effect on economic growth of West Papua.

- It is assumed that special autonomy fund through fund for infrastructure sector has an effect on economic growth of West Papua.

- It is assumed that special autonomy fund through fund for people's economy has an effect on economic growth of West Papua.

- It is assumed that special autonomy fund through fund for other sectors has an effect on economic growth of West Papua.

\section{METHODS OF RESEARCH}

The research is conducted in West Papua which is one of the three provinces that central government has granted the status of a special autonomy. It makes use of secondary data, compiled by asking data directly to relevant institutions and studying the published data such as reports, archives, bulletin of rules and official notes already available. For data analysis, it applies GSCA (Generalized Structured Component Analysis) analysis that can be run by means of GeSCA which is the only online SEM software available today. This is right tool for the research for several reasons. For one, it does not require multivariate normality. Another is that it can still work even with small size.

\section{RESULTS AND DISCUSSION}

Direct Effect Hypothesis Testing. Direct effect hypothesis testing is conducted to find out the direct effects of exogenous variables on endogenous variables. The presence or absence of the effect can be confirmed by looking into critical ratio (CR) value. Ifcritical ratio (CR) has star mark or $\geq t$-table $(t=2.00$, alpha $=5 \%$ ), it indicates the presence of significant effect of exogenous variable on endogenous variable. The whole results are presented in the following table:

Table 1 - Hypothesis Testing Based on critical ratio (CR) value

\begin{tabular}{|l|l|l|l|l|}
\hline Exogenous Variable & Endogenous Variable & Path Coefficient & SE & CR \\
\hline Fund & Education & 0.666 & 0.133 & $5.02^{*}$ \\
\hline Fund & Health & 0.752 & 0.086 & $8.77^{*}$ \\
\hline Fund & Economy & 0.392 & 0.133 & $2.95^{*}$ \\
\hline Fund & Infrastructure & 0.304 & 0.174 & 1.74 \\
\hline Fund & Affirmative & 0.579 & 0.093 & $6.19^{*}$ \\
\hline Fund & Economic Growth & -2.034 & 1.646 & 1.24 \\
\hline Education & Economic Growth & 0.914 & 0.932 & 0.98 \\
\hline Health & Economic Growth & 0.074 & 0.477 & 0.16 \\
\hline Economy & Economic Growth & 0.801 & 0.431 & 1.86 \\
\hline Infrastructure & Economic Growth & 1.109 & 0.614 & 1.8 \\
\hline Affirmative & Economic Growth & 1.213 & 1.056 & 1.15 \\
\hline Economic Growth & Fund & -0.015 & 0.183 & 0.08 \\
\hline
\end{tabular}

Note: * Significant. 
Indirect Effect Hypothesis Testing. This kind of testing is to find out the presence or absence of the indirect effects of exogenous variables on endogenous variables through mediators. Indirect effect hypothesis testing. It can be conducted by looking into T-statistics value. If Tstatistics $\geq t$-tabel $(t=1.96$, alpha $=5 \%$ ) holds, it indicates the presence of significant effect of exogenous variables on endogenous variables through mediating variables. The whole results are presented in the following table:

Table 2 - Indirect Effect Hypothesis Testing

\begin{tabular}{|l|l|l|l|l|l|}
\hline Exogen & Med 1 & Endogen & Indirect & SE & T statis-tics \\
\hline Fund & Education & Economic Growth & 0.609 & 0.633 & 0.962 \\
\hline Fund & Health & Economic Growth & 0.056 & 0.359 & 0.155 \\
\hline Fund & Economy & Economic Growth & 0.314 & 0.200 & 1.572 \\
\hline Fund & Infrastructure & Economic Growth & 0.337 & 0.268 & 1.256 \\
\hline Fund & Affirmative & Economic Growth & 0.702 & 0.622 & 1.130 \\
\hline Education & Economic Growth & Fund & -0.014 & 0.168 & -0.082 \\
\hline Health & Economic Growth & Fund & -0.001 & 0.015 & -0.072 \\
\hline Economy & Economic Growth & Fund & -0.012 & 0.147 & -0.082 \\
\hline Infrastructure & Economic Growth & Fund & -0.017 & 0.203 & -0.082 \\
\hline Affirmative & Economic Growth & Fund & -0.018 & 0.223 & -0.082 \\
\hline
\end{tabular}

Conversion of Path Diagram into Structural Model. The conversion is important to find out the presence or absence of direct or indirect effects exogenous variables on endogenous variables through mediating variables. The whole results are presented in the following table:

Table 3 - The Direct and Indirect Effects of Exogenous Variables on Endogenous Variables

\begin{tabular}{|l|l|l|l|l|l|}
\hline Exogenous Variable & Mediation & Endogenous Variable & Direct & Indirect & Total \\
\hline Fund & & Education & $0.666^{*}$ & & $0.666^{*}$ \\
\hline Fund & & Health & $0.752^{*}$ & & $0.752^{*}$ \\
\hline Fund & & Economy & $0.392^{*}$ & & $0.392^{*}$ \\
\hline Fund & & Infrastructure & 0.304 & & 0.304 \\
\hline Fund & & Affirmative & $0.579^{*}$ & & $0.579^{*}$ \\
\hline Fund & Education & Economic Growth & & 0.609 & -1.425 \\
\hline Fund & Health & Economic Growth & & 0.056 & -1.978 \\
\hline Fund & Economy & Economic Growth & -2.034 & 0.314 & -1.720 \\
\hline Fund & Infrastructure & Economic Growth & & 0.337 & -1.697 \\
\hline Fund & Affirmative & Economic Growth & & 0.702 & -1.332 \\
\hline Education & & Economic Growth & 0.914 & & 0.914 \\
\hline Health & & Economic Growth & 0.074 & & 0.074 \\
\hline Economy & Economic Growth & 0.801 & & 0.801 \\
\hline Infrastructure & & Economic Growth & 1.109 & & 1.109 \\
\hline Affirmative & & Economic Growth & 1.213 & & 1.213 \\
\hline Economic Growth & & Fund & -0.015 & & -0.015 \\
\hline Education & & Fund & & -0.014 & -0.014 \\
\hline Health & Economic Growth & Fund & & -0.001 & -0.001 \\
\hline Economy & Economic Growth & Fund & & -0.012 & -0.011 \\
\hline Infrastructure & Economic Growth & Fund & -0.017 \\
\hline Affirmative & Economic Growth & Fund & -0.018 & -0.018 \\
\hline
\end{tabular}

Note: * Significant.

\section{DISCUSSION OF RESULTS}

The effects among variables involved in the study are delineated by means of GSCA. The analysis goes further as to the reasons behind the relations, compatibility between theories and facts concerning the relations, and the possible effects it will bring to literature and policy makers. It in turn might lead to theory contribution that would enrich literature.

The present research has several limitations that opens chances for further researches in the future. One limitation is its ability to cover all data as it concerns with many regional governments in West Papua such as province government of West Papua, South Manokwari 
regency government, Arfak Mountains regency government, Tambraw Regency government, Maybrat regency government, South Sorong regency government, Sorong regency government, Raja Ampat regency government, Fak-fak regency government, Kaimana regency government and Sorong municipality government. Area width and data incompleteness hinders data collection that makes this study only uses data of 2013 and 201, instead of that fact that special autonomy policy has started since 2009. Accordingly, further researches might continue comparable study with more complete data.

\section{CONCLUSION AND SUGGESTIONS}

The study intends to find out the effect of special autonomy fund allocation on economic growth in West Papua. From analysis results and discussion above, there are some conclusions that can be drawn as follows:

1. GSCA analysis results show that special autonomy fund allocation on economic growth in West Papua has 1,24critical ratio (cr) without star mark. It means that fund allocation does not have a direct significant effect on economic growth. While it has indirect effects through funds for education, health, people's economy and affirmative sectors on economic growth. It excludes infrastructure sector as its mediating variable.

2. There have been factors due to fund allocation and special autonomy for West Papua that might lead to ineffective special autonomy fund government. These factors need special attention to tackle.

3. The outcomes of Special Autonomy and the fund in West Papua might include:

- There has been continuous increase in economic growth of West Papua from year to year;

- There has been stark decrease in poverty and unemployment rates;

- There has been increase in people income;

- There has been stark increase in number of infrastructures including roads, school building, hospitals, and others from year to year.

Special autonomy and its fund for West Papua focus on 5 sectors that has direct impact on indigenous people including: education, health, infrastructure, people's economy and affirmation/other sectors. The policy itself does not guarantee of bringing the expected results. On the part of West Papua regional governments, the success of the policy lies on their capability to ensure the fund governance in every sector. The fund governance has been critical issue faced by almost all governments. This requires special attention for central government and regional government as fund recipients to make some improvement and related preparation to make sure its governance, especially in every sector the fund aims to develop.

\section{REFERENCES}

1. Agustino, Leo. 2005. PolitikdanOtonomi Daerah. Jakarta: Untirta Press.

2. BPK RI. Kajian Atas Pengelolaan Dan Pertanggung Jawaban Dana Otonomi Khusus Provinsi Papua,Papua Barat dan Provinsi Aceh." Retrieved from http://www.dpr.go.id/doksetjen/dokumen/bpkdpd Analisa Pengelolaan \& Pertanggung jawaban Dana Otsus Prov. Papua, Papua Barat \& NAD.

3. Bappeda Provinsi Papua Barat. Perkembangan Provinsi Papua Barat 2014, Seri Analisa Pembangunan Daerah."Retrieved from H Wijaya - Jurnal Coopetition, 2017 - ikopin.ac.id

4. Bappeda Provinsi Papua Barat. Analisis Pembangunan Provinsi Papua Barat 2015, Seri Analisa Pembangunan Daerah. Retrieved from H Wijaya - Jurnal Coopetition, 2017 ikopin.ac.id.

5. BPS Provinsi Papua Barat. Papua Barat Dalam Angka 2014.

6. Djohan, Djoharmansyah. (2003). Kebijakan Otonomi Daerah 1999. Jakarta: Yarsif Watampone. 
7. Djopari, John RG. (1993). Pemberontakan Organisasi Papua Merdeka. Jakarta: Grasindo.

8. Dunn, William. 2003. Analisis Kebijakan Publik. Yogyakarta: UGM Press.

9. Institute for Local Development. (2005). Pasang Surut Otonomi Daerah: Sketsa Perjalanan 100 Tahun. Jakarta: Yayasan TIFA.

10. Kasiepo, Manuel. 1987. Pembangunan Masyarakat Pedalaman Irian Jaya. Jakarta: Pustaka Sinar Harapan.

11. Koentjoroningrat. 1994. Irian Jaya Membangun Masyarakat Majemuk. Jakarta: Djambaran.

12. Maniagasi, Frans. 2001. Masa DepanPapua: Merdeka, OtonomiKhusus dan Dialog. Jakarta: Milinium Publisher.

13. Mudrajad Kuncoro. 2014. OtonomiDaerahMenuju Era BaruPembangunandaerah, Edisi 3: Erlangga.

14. Pattiro, 2013. Efektivitas Dana otonomi Khusus di papua dan Papua Barat. "Retrieved from http://pattiro.org/2013/04/memo kebijakan efektivitas dana otonomi khusus di papua dan papua barat.

15. Sumule, Agus. 2002. Mencari Jalan Tengah: Otonomi Khusus Provinsi Papua. Jayapura: Uncen.

16. Sub bagian Hukum BPK Perwakilan Provinsi Papua Barat. Audit Dana Otsus Papua dan Papua Barat sejak Tahun 2001."Retrieved from http://manokwari.bpk.go.id/wpcontent/uploads/2016/08/audit-dana-otsus-papua-dan-papua-barat-sejak-tahun-2001. 